\title{
POULTRY CARCASS DECOMPOSITION AND PHYSICOCHEMICAL ANALYSIS OF COMPOUNDS IN DIFFERENT COMPOSTER TYPES
}

\author{
TAIANA CESTONARO ${ }^{1}$, PAULO G. DE ABREU ${ }^{2}$, VALÉRIA M. N. ABREU ${ }^{3}$, \\ LETÍCIA DOS S. LOPES ${ }^{4}$, ARLEI COLDEBELLA ${ }^{5}$
}

\begin{abstract}
This study aimed to assess five composter types in poultry carcasses decomposition and to perform a physicochemical analysis of the compounds obtained. Composter types used were six-hole brick, wood, screen, windrow with three PVC pipes with six holes and windrow with three PVC pipes with 10 holes. Composting was followed by four periods using wood shaving like substrate with one bird carcass placed in each composter. Pile turning was performed every 10 days and temperature in each layer was measured on $1^{\text {st }}, 7^{\text {th }}, 14^{\text {th }}, 19^{\text {th }}$ and $29^{\text {th }}$ day, at 3 p.m., as well as room temperature. Temperature during pile turning was also measured at five points per layer and carcass weighing performed to calculate decomposition percentage. Physicochemical parameters evaluated in substrates were moisture, ash, phosphorus, potassium, nitrogen, $\mathrm{pH}$, organic carbon and $\mathrm{C} / \mathrm{N}$ ratio, up to 30 days. Data were analyzed by repeated measures model, using MIXED method of SAS software. All values of final physicochemical composition of substrates were found according to values of IN-25, except nitrogen. The composter types were efficient in decomposition of poultry carcasses.
\end{abstract}

KEYWORDS: composting, organic fertilizers, substrate.

\section{DECOMPOSIÇÃO DAS CARCAÇAS DE AVES E ANÁLISE FÍSICO-QUÍMICA DOS COMPOSTOS EM DIFERENTES TIPOS DE COMPOSTEIRA}

RESUMO: Objetivou-se avaliar cinco tipos de composteira na decomposição das carcaças de aves e analisar físico-quimicamente os compostos obtidos. Os tipos de composteira utilizados foram: tijolo com sei furos, madeira, tela, leira com três tubos de PVC com seis furos e leira com três tubos de PVC com 10 furos. A compostagem foi acompanhada por quatro períodos utilizando a maravalha como substrato. Em cada composteira, foi colocada uma carcaça de ave. O tombamento das pilhas foi realizado a cada 10 dias. A temperatura em cada camada foi medida no $1^{\underline{0}}, 7^{\circ}, 14^{\underline{0}}, 19^{\circ}$ e $29^{0}$ dia, às $15 \mathrm{~h}$, bem como a temperatura ambiente. Também foi medida a temperatura no tombamento das pilhas, em cinco pontos por camada, e realizada a pesagem das carcaças para o cálculo da porcentagem de decomposição. Os parâmetros físico-químicos avaliados nos substratos foram: umidade, cinzas, fósforo, potássio, nitrogênio, $\mathrm{pH}$, carbono orgânico e relação $\mathrm{C} / \mathrm{N}$, até os 30 dias. Os dados foram analisados por meio do modelo de medidas repetidas, utilizando o procedimento MIXED do SAS. Todos os valores da composição físico-química final dos substratos encontraram-se de acordo com os valores da IN-25, exceto o nitrogênio. Os tipos de composteira foram eficientes na decomposição das carcaças de aves.

PALAVRAS-CHAVE: compostagem, fertilizantes orgânicos, substrato.

\footnotetext{
${ }^{1}$ Eng $^{\mathrm{a}}$ Ambiental, Doutoranda em Saneamento, Meio Ambiente e Recursos Hídricos, UFMG, Belo Horizonte - MG, Fone: (31) 9135-8235, tcestonaro@hotmail.com

${ }^{2}$ Eng $^{0}$ Agrícola, Pesquisador, Embrapa Suínos e Aves, Concórdia - SC, paulo.g.abreu@embrapa.br

${ }^{3}$ Zootecnista, Pesquisadora, Embrapa Suínos e Aves, Concórdia - SC, valeria.abreu@embrapa.br

${ }^{4}$ Estatística, Analista, Embrapa Suínos e Aves, Concórdia - SC, leticia.lopes@embrapa.br

${ }^{5}$ Médico Veterinário, Pesquisador, Embrapa Suínos e Aves, Concórdia - SC, arlei.coldebella@embrapa.br

Recebido pelo Conselho Editorial em: 22-11-2012

Aprovado pelo Conselho Editorial em: 10-3-2014
} 


\section{INTRODUCTION}

Brazilian broiler industry has shown great dynamism in recent years. Chicken meat is the most produced, consumed and exported animal protein in the country. Moreover, this activity also stands out on the world scene, in which Brazil is the largest exporter and third largest chicken meat producer (UBABEF, 2013).

Considering the significant participation in domestic and foreign market, the activity needs attention in environmental control, since it generates potentially polluting waste, such as dead bird carcasses. These wastes require treatment for later disposal on the environment. When treated, they can be applied as organic fertilizer, which reduces the producer's costs and contributes to physical, chemical, physicochemical and biological soil properties, correcting and improving its fertility (LUCHESE et al., 2001).

Aiming environmental control, as well as the recycling of the nutrients in question, several techniques can be employed, such as composting. This is a safe and economical technique for the treatment of solid waste and concerns their microbial transformation, aerobically, resulting in a stabilized and sanitized product, beneficial to plant growth (STENTIFORD \& BERTOLDI, 2011). Several authors have already proved their efficiency in agro-industrial waste, such as slaughterhouse waste (COSTA et al., 2009; KABORÉ et al., 2010) and dead animal carcasses (CESTONARO et al., 2010; ORRICO JUNIOR et al., 2010).

For the process to occur efficiently, some parameters need to be monitored. Temperature, which correlates with physicochemical and microbiological parameters from composting, is a simple and inexpensive means for this purpose (KIEHL, 2010).

Furthermore, the type of composter adopted may also influence the development process and the quality of the final product. Composters are structures in which residue is disposed, intended to be composted. Depending on building characteristics and material used in its manufacturing, they can provide different aeration and handling conditions for the material.

As financial resources and availability of materials for this purpose vary between farms, we aimed to evaluate five composter types considering decomposition of poultry carcasses and physicochemical properties of the compost.

\section{MATERIAL AND METHODS}

The experiment was conducted at Embrapa Swine and Poultry, Experimental Field in Suruvi Concórdia - SC, Brazil, and the trial period was from August 2008 to February 2009.

Five composter types were used: brick with six holes $(1 \mathrm{~m}$ height, $0.70 \mathrm{~m}$ width and $0.70 \mathrm{~m}$ depth); wood (1 m height, $0.70 \mathrm{~m}$ width and $0.70 \mathrm{~m}$ depth), screen (1 m height, $0.70 \mathrm{~m}$ diameter and mesh screen of $0.014 \mathrm{~m} \times 0.10 \mathrm{~m}$ ), windrow with three PVC pipes with six holes and windrow with three PVC pipes and 10 holes (Figure 1). 

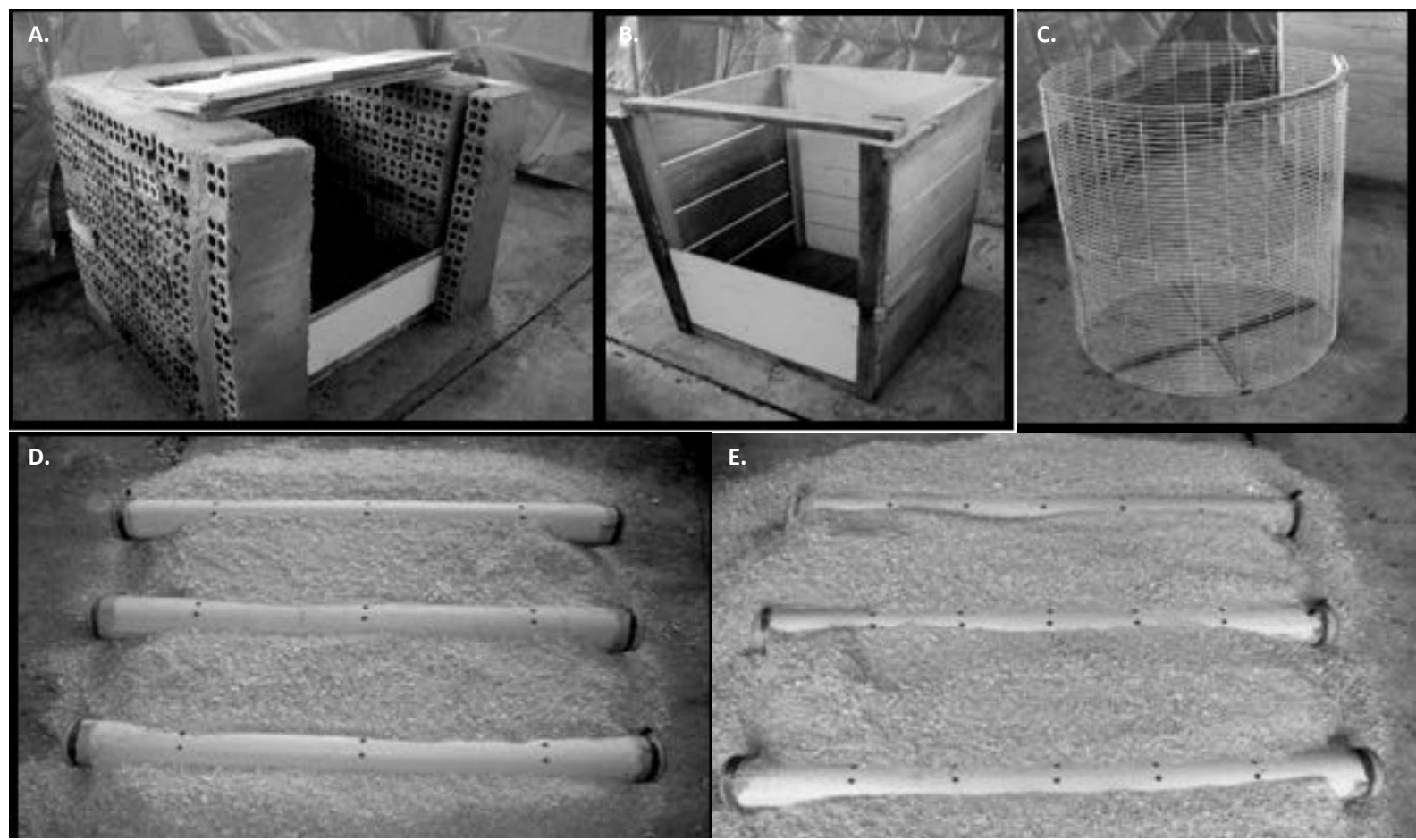

The PVC pipes were placed at the base of each windrow for aeration and the substrate used in all composters was the shavings.

FIGURE 1. Composters images: A. brick with six holes; B. wood; C. screen; D. windrow with three PVC pipes with 6 holes; E. windrow with three PVC pipes with 10 holes.

Composting was performed in four periods of 30 days each, with first period assembly in the winter, second and third periods in the spring and fourth period in the summer. Each composter pile was assembled in three layers with thickness of $0.40,0.10$ and $0.30 \mathrm{~m}$, upper, middle, and bottom, respectively. A poultry carcass was deposited in the middle layer of each composter type.

The birds used in composting were slaughtered, remaining in aviary on bed for $24 \mathrm{~h}$, simulating field situation. Each bird was weighed to calculate the amount of water to be added at turning. This amount was equivalent to 30\% of the bird weight (ABREU et al., 2011), which had an initial average weight of $2.30 \mathrm{~kg}$.

Pile turning was performed every ten days, aiming to aerate the substrate, reassembling pile with the same order of layers and damping carcasses again. At pile assembly and at each turning the weighing of carcasses was performed to calculate the percentage of decomposition. An electronic weighing scale Toledo® brand, 2124-C5 model was used, with a capacity of $100 \mathrm{~kg}$. After 30 days, final turning was carried out.

In each turning five substrate subsamples were collected at different points, by layer, for each composter. The subsamples were homogenized and originated a single sample per layer used for physicochemical analysis. Moisture content, ash, phosphorus (P), potassium (K), total Kjeldahl nitrogen $(\mathrm{TKN})$ and $\mathrm{pH}$ were verified and the $\mathrm{C} / \mathrm{N}$ ratio was calculated.

Equation (1) was used for determination of organic carbon (SILVA, 1999):

M.O. $=1,724 \times \mathrm{C}$

where,

M.O. - organic matter (\%), and

$\mathrm{C}$ - organic carbon (\%).

Temperature in each layer of composter models was measured on $1^{\text {st }}, 7^{\text {th }}, 14^{\text {th }}, 19^{\text {th }}$ and $29^{\text {th }}$ day at 15 p.m., by means of thermocouples fixed in rods and located at the geometric center of layers. Each layer temperature was also measured at five points, during composters turning, on $10^{\text {th }}$, 
$20^{\text {th }}$ and $30^{\text {th }}$ days of composting, using a digital electronic thermometer with Rifran ${ }^{\circledR}$ temperature probe.

Statistical analysis for physicochemical variables was performed using an average of the 3 compost layers through repeated measure models, using MIXED method of SAS (2003) according to XAVIER (2000), testing 15 variance and covariance structures, by choosing one with the lowest value for Akaike Information Criterion (AIC). Period effects, composting time, composter type and interactions between them were tested. Post analysis of effects was performed using the $t$ test at 5\% significance level.

Period consisted of four trial repetitions performed in time, with first period in the winter, second and third periods in the spring and fourth period in the summer. During the composting time, four sample collections were performed, in 0; 10; 20 and 30 days of each period. Treatments consisted of five composter types: brick with six holes, wood, screen, windrow with three PVC pipes with six holes and windrow with three PVC pipes with 10 holes.

\section{RESULTS AND DISCUSSION}

For poultry carcass degradation, significant effect $(p<0.05)$ was only observed for composting time. All composter types presented decomposition values above $75 \%$ after 30 days of composting (Figure 2).

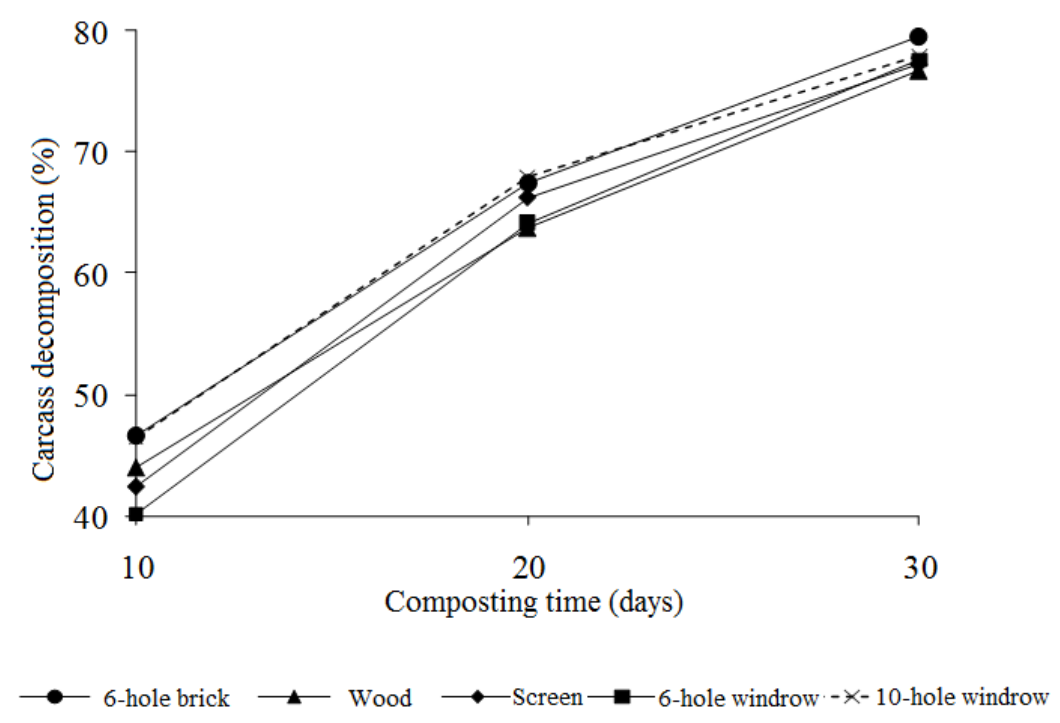

FIGURE 2. Average profiles of poultry carcass decomposition (\%) versus composting time for different composter types.

High degradation values observed in this work, in short time, are because only carcass decomposition was evaluated, not taking into account substrate decomposition (wood shavings). Due to its high lignin and cellulose content, 24 and 57\%, respectively (LECONTE et al., 2009), wood shavings particularly experienced mechanical fragmentation during turning, since conditions under which experiment was conducted, such as short composting time, low substrate humidity and absence of temperature thermophilic phase, do not provide adequate conditions for decomposition.

These results corroborate with CESTONARO et al. (2010) and ABREU et al. (2011) who found high degradation levels ( $>65 \%$ and $59-65 \%$, respectively) of poultry carcasses composted with alternative substrates. On the other hand, SIVAKUMAR et al. (2008) obtained a reduction of lower volume in the range from 39.0 to $59.3 \%$, since total mass degradation in composting was evaluated, not only carcasses.

There was significant effect $(\mathrm{p}<0.05)$ for temperature in period, composting time and composter type. Figure 3 shows substrate average temperature in composter types, related to 
composting time. At final composting stage ( $29^{\text {th }}$ day) temperature decreased for all composters, showing the depletion of organic matter readily available to microorganisms.

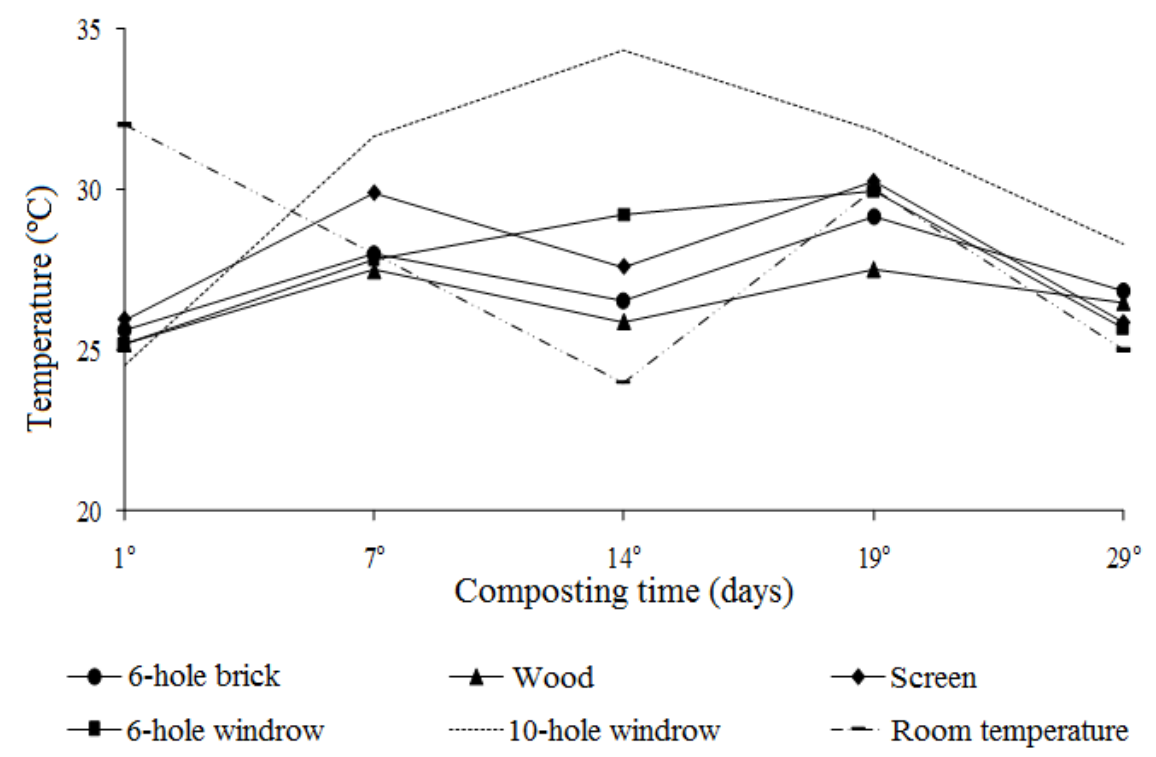

FIGURE 3. Temperature average values of substrates in composter types and room temperature related to composting time.

Figure 4 shows the substrate average temperature, by composter, related to pile turning days. There were significant effects $(\mathrm{p}<0.05)$ for period and composting time.

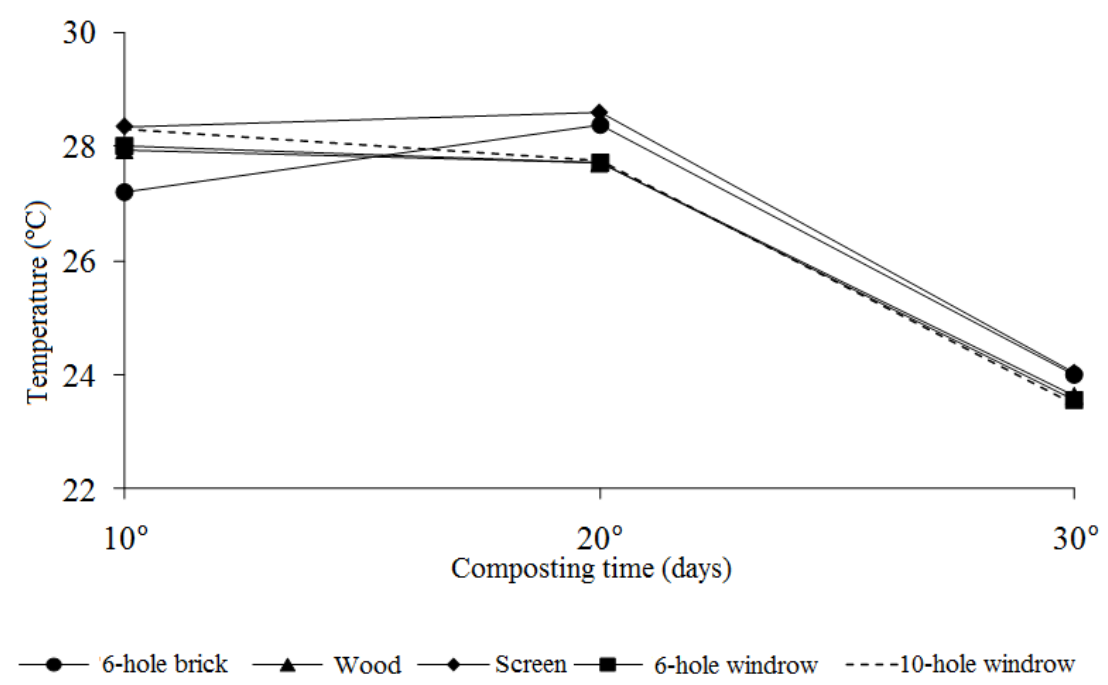

FIGURE 4. Substrate average temperature in composter models related to pile turning days.

Temperatures recorded in this study were lower than those reported in literature. The use of a substrate (wood shavings) with high $\mathrm{C} / \mathrm{N}$ ratio (Table 2), difficult to decompose, added to limited organic matter (poultry carcass) readily available to microorganisms, contributed to this behavior. Once self-heating ability of the material is highly correlated with the amount of biodegradable matter (GUARDIA et al., 2010), failing that, the optimum temperature values were not achieved, advocated by KIEHL (2010), between $45^{\circ} \mathrm{C}$ to $65^{\circ} \mathrm{C}$, and by USEPA (1994), of $55^{\circ} \mathrm{C}$ for three days for pathogen elimination.

ORRICO JÚNIOR et al. (2010) obtained an average temperature of $50{ }^{\circ} \mathrm{C}$ in first 27 days of poultry carcass composting. However, carcasses were composted along with poultry litter, which is partially decomposed material and has amount of manure, thereby increasing available carbon source and the amount of microorganisms acting on decomposition. CURCI et al. (2007) also obtained higher temperatures than gotten in this study $\left(40.5\right.$ to $52.4^{\circ} \mathrm{C}$ ), in the composting of 
bovine carcasses, a result to be expected once bovine carcass has a higher amount of organic matter available for microbial activity.

Despite the fact that temperature values found are not in accordance with literature, there was decomposition of poultry carcasses. However, a second stage in poultry carcasses composting is necessary in order to ensure process biosecurity (COSTA et al., 2006).

Table 1 shows descriptive probability levels of $\mathrm{F}$ test of variance analysis for physicochemical composition of the compost.

TABLE 1. Descriptive probability levels of $\mathrm{F}$ test of variance analysis for physicochemical composition of the compost obtained from poultry carcasses composting by composter types.

\begin{tabular}{lcccc}
\hline \multirow{2}{*}{ Variable } & \multicolumn{3}{c}{ Pr $>\mathrm{F}$} \\
\cline { 2 - 5 } & Period & Composting Time & Composter & $\begin{array}{c}\text { Composting Time } \\
\text { x Composter }\end{array}$ \\
\hline C/N ${ }^{1}$ & $<\mathbf{0 . 0 0 0 1}$ & $\mathbf{0 . 0 0 0 4}$ & 0.2277 & 0.8143 \\
C. Org $^{2}$ & $\mathbf{0 . 0 0 5 4}$ & 0.1037 & 0.4861 & 0.6055 \\
Ashes $^{2}$ & $\mathbf{0 . 0 0 5 4}$ & 0.1037 & 0.4861 & 0.6055 \\
$\mathrm{~K}^{1}$ & $<\mathbf{0 . 0 0 0 1}$ & $\mathbf{0 . 0 4 8 5}$ & 0.0528 & 0.2397 \\
Humidity $^{3}$ & $\mathbf{0 . 0 0 1 4}$ & 0.0646 & 0.6631 & 0.2067 \\
NTK $^{1}$ & $<\mathbf{0 . 0 0 0 1}$ & $\mathbf{0 . 0 1 7 8}$ & $\mathbf{0 . 0 3 5 0}$ & 0.5430 \\
$\mathrm{P}^{4}$ & 0.0577 & $\mathbf{0 . 0 2 9 7}$ & 0.2962 & 0.4267 \\
pH $^{5}$ & $<\mathbf{0 . 0 0 0 1}$ & $\mathbf{0 . 0 1 6 4}$ & 0.0572 & 0.4063 \\
\hline
\end{tabular}

Types of variance and covariance matrices used: ${ }^{1}$ Autoregressive moving average of order $1 ;{ }^{2}$ Heterogeneous autoregressive of order 1; ${ }^{3}$ Huynh Feldt; ${ }^{4}$ No Structure; ${ }^{5}$ First Antedependence.

All variables showed significant effects $(\mathrm{p}<0.05)$ for period, except phosphorus. Because the composting periods were allocated in different seasons, variations in temperature, humidity and even used material characteristics may have contributed to changes in final compost characteristics.

Regarding composting time, there was significant effect $(\mathrm{p}<0.05)$ of the variables $\mathrm{C} / \mathrm{N}$ ratio, $\mathrm{K}, \mathrm{TKN}, \mathrm{P}$ and $\mathrm{pH}$. Differences are due to changes in nutrient concentration throughout the process. As already established in composting, some nutrients present in the medium can detach in gas form, leach with irrigation water, as well as concentrate due to organic matter consumption by microorganisms (STENTIFORD \& BERTOLDI, 2011).

There was significant effect $(\mathrm{p}<0.05)$ of nitrogen variable for composter type. The differences for this variable may have been due to carcass size, which increased different nitrogen concentrations in compost (Table 3).

Table 2 shows average values and standard errors of initial physicochemical composition of substrates for composter types.

TABLE 2. Averages and standard errors of initial physicochemical composition of substrates for composter types.

\begin{tabular}{lccccc}
\hline \multirow{2}{*}{ Parameter } & \multicolumn{4}{c}{ Composter types } \\
\cline { 2 - 6 } & Brick with 6 holes & Wood & Screen & $\begin{array}{c}\text { Windrow with 6 } \\
\text { holes }\end{array}$ & $\begin{array}{c}\text { Windrow with 10 } \\
\text { holes }\end{array}$ \\
\hline C. Org (\%) & $57.7 \pm 0,04$ & $57.7 \pm 0.02$ & $57.7 \pm 0.04$ & $57.7 \pm 0.01$ & $57.7 \pm 0.07$ \\
Humidity (\%) & $12.2 \pm 1.7$ & $11.8 \pm 1.6$ & $12.7 \pm 2.2$ & $12.6 \pm 1.6$ & $12.6 \pm 1.9$ \\
NTK (\%) & $0.25 \pm 0.04$ & $0.28 \pm 0.06$ & $0.54 \pm 0.2$ & $0.27 \pm 0.06$ & $0.32 \pm 0.09$ \\
P (\%) & $0.04 \pm 0.002$ & $0.04 \pm 0.006$ & $0.04 \pm 0.006$ & $0.04 \pm 0.002$ & $0.04 \pm 0.004$ \\
K (\%) & $0.09 \pm 0.004$ & $0.1 \pm 0.01$ & $0.1 \pm 0.01$ & $0.09 \pm 0.005$ & $0.1 \pm 0.01$ \\
pH & $5.6 \pm 0.4$ & $5.7 \pm 0.5$ & $5.8 \pm 0.6$ & $5.7 \pm 0.5$ & $6.7 \pm 0.9$ \\
C/N & $242 \pm 30.8$ & $232 \pm 41.4$ & $194 \pm 28.6$ & $241 \pm 46.1$ & $206 \pm 45.4$ \\
Ashes (\%) & $0.50 \pm 0.1$ & $0.52 \pm 0.03$ & $0.55 \pm 0.1$ & $0.43 \pm 0.03$ & $0.49 \pm 0.1$ \\
\hline
\end{tabular}


From Table 2 very similar nutrient levels are verified between evaluated composters due to same substrate used. As initial physicochemical composition corresponds to the process beginning, there is no increase in nutrients from carcasses in compost substrate yet. The largest discrepancies were observed for nitrogen in screen composter. This value may be due to sample contamination, given that in physicochemical composition of the compost (Table 3) there was a decrease in nitrogen concentration only in this composter.

Moisture content was below optimum range cited by KIEHL (2010), from 40 to 60\%, since samples were performed in substrate layers, and water was added only to carcass. Substrate C/N ratio was well above 28/1 indicated by GAO et al. (2010), which promotes compost maturation and stability. Despite the optimal values for this parameter, initial $\mathrm{C} / \mathrm{N}$ ratio can be variable, but it will influence factors such as nitrogen dynamics (VELASCO- VELASCO et al., 2011). According to ZHU (2007), a lower C/N ratio decreases producer costs, because greater amount of waste is composted with less straw-like material, but it has disadvantages such as shorter time in thermophilic phase and increased nitrogen losses.

Table 3 shows the average values and standard errors of final physicochemical composition of the substrates by composter types.

TABLE 3. Averages and standard errors of compost physicochemical composition in the composter types and values recommended by Normative Instruction 25 (IN 25) by MAPA (2009).

\begin{tabular}{lcccccc}
\hline \multirow{2}{*}{ Parameter } & \multicolumn{5}{c}{ Composter Types } & \multirow{2}{*}{ IN-25 } \\
\cline { 2 - 6 } & \multirow{2}{*}{ Brick } & \multirow{2}{*}{ Wood } & Screen & $\begin{array}{c}\text { Windrow with } \\
6 \text { holes }\end{array}$ & $\begin{array}{c}\text { Windrow with } \\
10 \text { holes }\end{array}$ & \\
\hline C. Org (\%) & $57.7 \pm 0.03$ & $57.7 \pm 0.02$ & $57.6 \pm 0.11$ & $57.5 \pm 0.11$ & $57.7 \pm 0.02$ & $\geq 15$ \\
Humidity (\%) & $13.8 \pm 0.9$ & $13.3 \pm 0.5$ & $13.5 \pm 0.5$ & $14.8 \pm 1.1$ & $14.1 \pm 0.9$ & $\leq 40$ \\
NTK (\%) & $0.30 \pm 0.04 \mathrm{a}$ & $0.31 \pm 0.05 \mathrm{ab}$ & $0.40 \pm 0.1 \mathrm{c}$ & $0.39 \pm 0.05 \mathrm{bc}$ & $0.37 \pm 0.05 \mathrm{abc}$ & $\geq 0.5$ \\
P (\%) & $0.05 \pm 0.002$ & $0.05 \pm 0.002$ & $0.07 \pm 0.02$ & $0.06 \pm 0.004$ & $0.05 \pm 0.003$ & \\
K (\%) & $0.097 \pm 0.01 \mathrm{ab}$ & $0.093 \pm 0.01 \mathrm{a}$ & $0.111 \pm 0.01 \mathrm{bc}$ & $0.118 \pm 0.01 \mathrm{c}$ & $0.112 \pm 0.01 \mathrm{bc}$ & \\
pH & $6.8 \pm 0.2$ & $6.6 \pm 0.2$ & $7.2 \pm 0.2$ & $7.8 \pm 0.5$ & $7.2 \pm 0.5$ & \multirow{2}{*}{ c.d* } \\
C/N & $224 \pm 35.5$ & $210 \pm 37.3$ & $185 \pm 34.7$ & $162 \pm 26.0$ & $174 \pm 33.5$ & \\
Ashes (\%) & $0.6 \pm 0.1$ & $0.5 \pm 0.04$ & $0.7 \pm 0.2$ & $0.9 \pm 0.2$ & $0.6 \pm 0.03$ & \\
\hline
\end{tabular}

* as stated; Means followed by different letters in rows differ from each other by $t$ test $(\mathrm{p}<0.05)$.

It is noted that the same similarity found between composters at the beginning of composting (Table 2) remained at the final compost (Table 3). The increase of nutrients in substrate, from poultry carcass decomposition, provided no significant changes in this owed to small volume of carcass in relation to wood shaving volume. There was significant difference $(p<0.05)$ between composter types only for nitrogen and potassium parameters. As for nitrogen, screen composter showed the highest concentrations, not differing significantly $(\mathrm{p}<0.05)$ from windrows. For potassium, 6-hole windrow had the highest concentrations of the element, not differing significantly ( $p<0.05)$ from 10-hole windrow and from screen. This same behavior between the two elements may not have been influenced by composter type itself, but by size difference of the deposited carcasses, influencing greater aggregation of these nutrients in substrate.

Different from what is presented in most studies on composting (ORRICO JÚNIOR et al., 2010; BARRENA et al., 2009); there was an increase of nitrogen during process, a fact that is on account of poultry carcass decomposition. Besides the increase of this element, other characteristics contributed to its conservation in the substrate, as low temperature values (PAGANS et al., 2006) and high C/N ratio of the material (JIANG et al., 2011).

Considering initial physicochemical composition (Table 2) and final compost (Table 3) for composter types, it is noted in general that there was an increase in nutrient content, once de substrate, due to its difficult decomposition, showed no apparent reduction in volume which would allow nutrient concentration. 
Still in Table 3 , it appears that all values of the final physicochemical composition of substrates were in agreement with IN-25 regulation values, except nitrogen, which showed values below what is required for simple organic fertilizers. Nevertheless, it is recommended to reuse substrate to perform a new composting, also increasing the amount of organic matter in order to obtain temperatures which provide compost sanitization.

\section{CONCLUSIONS}

Changing the composter type did not affect poultry carcasses decomposition.

Although temperature was influenced by composter type, temperature differences did not affect other process factors.

The composting operating conditions allowed the conservation of nutrients for all composter models.

The final physicochemical composition of substrates was in accordance with IN-25 regulation values, except nitrogen.

A single poultry carcass used by composter made viewing of differences among the five studied composter types difficult.

\section{REFERENCES}

ABREU, P. G. de; PAIVA, D. P.; ABREU, V. M. N.; COLDEBELLA, A.; CESTONARO, T. Casca de arroz e palhada de soja na compostagem de carcaças de frangos de corte. Acta Scientiarum Animal Sciences, Maringá, v. 33, n. 1, p. 51-57, 2011.

BARRENA, R.; ARTOLA, A.; VÁZQUEZ, F.; SÁNCHEZ, A. The use of composting for the treatment of animal by-products: Experiments at lab scale. Journal of Hazardous Materials, Amsterdam, v. 161, n. 1, p. 380-386, 2009.

CESTONARO, T.; ABREU, P. G. de; ABREU, V. M. N.; COLDEBELLA, A.; TOMAZELLI, I. L.; HASSEMER, M. J. Desempenho de diferentes substratos na decomposição de carcaça de frango de corte. Revista Brasileira de Engenharia Agrícola e Ambiental, Campina Grande, v.14, n.12, p.1318-1322, 2010.

COSTA, M.S.S. de M.; COSTA, L. A. de M.; DECARLI, L.D.; PELÁ, A.; SILVA, C.J. da.; MATTER, U.F.; OLIBONE, D. Compostagem de resíduos sólidos de frigorífico. Revista Brasileira de Engenharia Agrícola e Ambiental, Campina Grande, v.13, n.1, p. 100-107, 2009.

COSTA, M.S.S. de M.; COSTA, L.A. de M.; PELÁ, A.; SILVA, C. J. da; DECARLI, L. D.; MATTER, U.F. Desempenho de quatro sistemas para compostagem de carcaça de aves. Revista Brasileira de Engenharia Agrícola e Ambiental, Campina Grande, v.10, n.3, p.692-698, 2006.

CURCI, V. C. L. M.; DUTRA, I. S.; DOBEREINER, J.; LUCAS JÚNIOR, J. Pré-compostagem de cadáveres de bovinos acometidos pelo botulismo. Pesquisa Veterinária Brasileira, Rio de Janeiro, v.27, n.4, p.157-161, 2007.

GAO, M.; LIANG, F.; YU, A.; LI, B.; YANG, L. Evaluation of stability and maturity during forced-aeration composting of chicken manure and sawdust at different $\mathrm{C} / \mathrm{N}$ ratios. Chemosphere, Oxford, v. 78, n. 5, p. 614-619, 2010.

GUARDIA, A. de; MALLARD, P.; TEGLIA, C.; MARIN, A.; LE PAPE, C.; LAUNAY, M.; BENOIST, J.C.; PETIOT, C. Comparison of five organic wastes regarding their behaviour during composting: Part 1, biodegradability, stabilization kinetics and temperature rise. Waste Management, Oxford, v. 30, n. 3, p. 402-414, 2010. 
JIANG, T.; SCHUCHARDT, F.; LI, G.; GUO, R.; ZHAO, Y. Effect of C/N ratio, aeration rate and moisture content on ammonia and greenhouse gas emission during the composting. Journal of Environmental Sciences, Los Angeles, v. 23, n. 10, p. 1754-1760, 2011.

KABORÉ, T. W.; HOUOT, S.; HIEN, E.; ZOMBRE, P.; HIEN, V.; MASSE, D. Effect of the raw materials and mixing ratio of composted wastes on the dynamic of organic matter stabilization and nitrogen availability in composts of Sub-Saharan Africa. Bioresource Technology, Essex, v. 101, n.3, p. 1002-1013, 2010.

KIEHL, E.J. Novos fertilizantes orgânicos. Piracicaba: Degaspari, 2010. 248 p.

LECONTE, M. C.; MAZZARINO, M. J.; SATTI, P.; IGLESIAS, M. C.; LAOS, F. Co-composting rice hulls and/or sawdust with poultry manure in NE Argentina. Waste Management, Oxford, v.29, n.9, p. 2446-2453, 2009.

LUCHESE, E. B.; FAVERO, L.O.B.; LENZI, E. Fundamentos da química do solo: teoria e prática. Rio de Janeiro: Freitas Bastos, 2001. 182 p.

MAPA. Ministério da Agricultura, Pecuária e Abastecimento. Instrução Normativa 25, de 23 de julho de 2009. Brasília, 2009.

ORRICO JUNIOR, M. A. P.; ORRICO, A. C. A.; LUCAS JÚNIOR, J. de. Compostagem dos resíduos da produção avícola: cama de frangos e carcaças de aves. Engenharia Agrícola, Jaboticabal, v. 30, n. 3, p. 538-545, 2010.

PAGANS, E.; BARRENA, R.; FONT, X.; SÁNCHEZ, A. Ammonia emissions from the composting of different organic wastes. Dependency on process temperature. Chemosphere, Oxford, v. 62, n. 9, p. 1534-1542, 2006.

SAS INSTITUTE. System for Microsoft Windows, release 9.1. Cary, 2003. CD-ROM.

SILVA, F.C. Manual de análises químicas de solos, plantas e fertilizantes. Brasília: EMBRAPA, 1999. $370 \mathrm{p}$.

SIVAKUMAR, K.; KUMAR, R. S.; JAGATHEESAN, P. N. R.; VISWANATHAN, K.;

CHANDRASEKARAN, D. Seasonal variations in composting process of dead poultry birds.

Bioresource Technology, Essex, v. 99, n. 9, p. 3708-3713, 2008.

STENTIFORD, E.; BERTOLDI, M. de. Composting: Process. In: CHRISTENSEN, T. H. (Ed).

Solid waste technology and management. New Jersey. John Wiley \& Sons, 2011. v.2, p. 515-532.

UBABEF. União Brasileira de Avicultura. Relatório anual 2013. São Paulo, 2013. 109 p.

Disponível em http://www.ubabef.com.br/publicacoes. Acesso em: 4 fev. 2014.

USEPA. Environmental Protection Agency. Composting yard trimmings and municipal solid waste. 1994. Disponível em: <http://www.epa.gov/wastes/conserve/composting/pubs/cytmsw.pdf >. Acesso em: 30 jul. 2012.

VELASCO-VELASCO, J.; PARKINSON, R.; KURI, V. Ammonia emissions during vermicomposting of sheep manure. Bioresource Technology, Essex, v. 102, n. 23, p. 10959-10964, 2011.

XAVIER, L.H. Modelos univariado e multivariado para análise de medidas repetidas e verificação da acurácia do modelo univariado por meio de simulação. 2000. 91 f. Dissertação (Mestrado) Escola Superior de Agricultura “Luiz de Queiroz”, Universidade de São Paulo, Piracicaba, 2000.

ZHU, N. Effect of low initial C/N ratio on aerobic composting of swine manure with rice straw. Bioresource Technology, Essex, v. 98, n. 1, p. 9-13, 2007. 